\title{
Synthesis and Antioxidant Properties of New Oxazole-5(4H)-one Derivatives
}

\section{Yeni Oksazol-5(4H)-one Türevlerinin Sentez ve Antioksidan Özellikleri}

\author{
Canan KUŞ*, Ezgi UĞURLU1', Elçin D. ÖZDAMAR², Benay CAN-EKE² \\ 'Ankara University, Faculty of Pharmacy, Department of Pharmaceutical Chemistry, Ankara, Turkey \\ ${ }^{2}$ Ankara University, Faculty of Pharmacy, Department of Pharmaceutical Toxicology, Ankara, Turkey
}

\begin{abstract}
Objectives: To synthesize and characterize 4-(substituted benzylidene)-2-(substituted phenyl)oxazol-5(4H)-one derivatives (E1-E10), and evaluate them for antioxidant activity.

Materials and Methods: Required oxazole-5(4H)-one derivatives were synthesized in two steps to obtain novel hippuric acid derivatives (7-13); glycine and acylated appropriate benzoic acid derivatives were used and then, final compounds were obtained with condensation of 7-13 with appropriate benzaldehydes (E1-E10). These products were purified by column chromatography using ethyl acetate/n-hexane as eluent. All the compounds were unequivocally characterized using the combination of ${ }^{1} \mathrm{H}$ and ${ }^{13} \mathrm{C}$-nuclear magnetic resonance, mass spectrometry (ESI-MS), and elemental analysis. The inhibition of lipid peroxidation and its effects on hepatic cytochrome P450-dependent ethoxyresorufin-O-deethylase (EROD) enzyme were determined in rats in vitro.
\end{abstract}

Results: The most active analogue on the microsomal EROD activity was E3 which inhibited the microsomal EROD activity (89\%) and was similarly better than that of the specific inhibitor caffeine (85\%) at 10-3 M concentration.

Conclusion: The findings of this study indicate that the synthesized compounds, such as E3, display significant antioxidant activity.

Key words: Oxazolidinones, synthesis, antioxidant activity, lipid peroxidation, EROD activity

ÖZ

Amaç: Bu çalışma, 4-(sübstitüe benziliden)-2-(sübstitüefenil)oksazol-5(4H)-on (E1-E10) türevlerini sentezlemek, yapılarını aydınlatmak ve antioksidan etkilerini araştırmaktır.

Gereç ve Yöntemler: Oksazol-5(4H)-on türevleri iki yolak ile sentezlenmiştir. Yeni hippürik asit türevlerini (7-13) elde etmek için, glisin ve açillenmiş uygun benzoik asitler kullanıldı ve bu bileșiklerin (7-13) uygun benzaldehitler ile kondensasyon reaksiyonu ile de sonuç ürünlere (E1-E10) ulaşılmıştır. Bu ürünler etil asetat/n-hekzan solvan sistemi kullanılarak kolon kromatografisi ile temizlenmiştir. Tüm bileşikler için ${ }^{1} \mathrm{H}$ and ${ }^{13} \mathrm{C}$-nükleer manyetik rezonans, mass spektrometresi (ESI-MS), elemental analiz yöntemleri kullanılarak yapıları tanımlanmıștır. Lipid peroksidasyon inhibisyonu ve karaciğer sitokrom P450 bağımlı Etoksirezorfin-O-deetilaz (EROD) enzimi üzerindeki etkileri sıçanlarda in vitro olarak tespit edildi.

Bulgular: Mikrozomal EROD aktivitesi üzerinde en aktif analog, EROD aktvitesini \%89 ile inhibe eden E3'tür, benzer şekilde 10-3 M konsantrasyonda spesifik inhibitör kafeinden (\%85) daha iyi idi.

Sonuç: Bu çalıșmanın bulguları, E3 gibi sentezlenen bileșiklerin, önemli antioksidan aktivite sergilediğini göstermektedir.

Anahtar kelimeler: Oksazolidinonlar, sentez, antioksidan aktivite, lipid peroksidasyon, EROD aktivite 


\section{INTRODUCTION}

Oxazolone ring is an important scaffold in the area of drug discovery. Oxazolone and its derivatives make a prominent structure of number of well established marketed drugs such as rilmenidine, furazolidone, nifurantoin, oxaprozin, and especially linezolid, which is an active against methicillin-resistant Staphylococcus aureus. Indeed, oxazolone based derivatives have shown diverse biological and pharmacological applications such as anticancer ${ }^{1,2}$, antibacterial ${ }^{3}$, antimycobacterial against tuberculosis ${ }^{4}$, and antioxidant ${ }^{5,6}$ activity.

Free radicals, such as hydroxyl, superoxide anion $\left(\mathrm{O}_{2}^{-}\right)$, nitric oxide (NO) and peroxide ion $\left(\mathrm{RO}_{2}\right)$, reactive oxygen species, are involved in different physiological processes. Antioxidants can act as direct scavengers of free radicals and reactive oxygen species, or they can indirectly metabolize free radicals or their intermediates into harmless products. Oxidative damage to DNA and other macromolecules appears to have a major role in aging, degenerative diseases and cancer. ${ }^{7-10}$ Due to oxidative cellular damage, development of cancers, cardiovascular diseases and ageing increase in the world. Antioxidant agents are able to either prevent or mitigate oxidative stress to cells that is an important area of investigation.

In light of the foregoing, novel oxazole-5(4H)-one derivatives were synthesized and evaluated their antioxidant activity. Molecular structure of designed compounds (E1-E10) is shown in Figure 1.

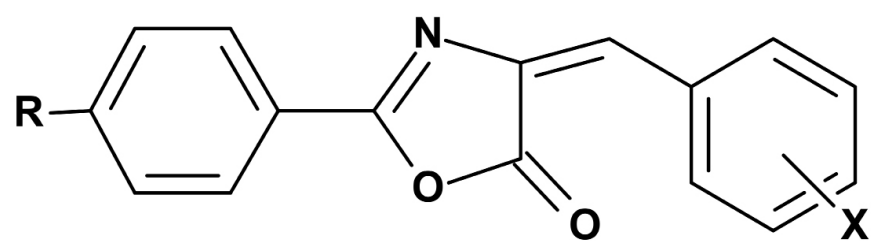

Figure 1. Molecular structure of designed compounds (E1-E10)

$\mathrm{R}=-\mathrm{H}, 4-\mathrm{F}, 4-\mathrm{CH}_{3}, 4-\mathrm{NO}_{2}, 4-\mathrm{Cl}, 4-\mathrm{OCH}_{3}, 4-\mathrm{Ph}$

$\mathrm{X}=-\mathrm{H}, 2,4-\mathrm{di}-\mathrm{F}, 2,4-\mathrm{di}-\mathrm{CH}_{3}, 4-\mathrm{Cl}$

In this study, firstly some of hippuric acid derivatives (7-13) were synthesized according to the literature. ${ }^{11-15}$ The synthetic route for hippuric acid derivatives (7-13) is displayed in Scheme 1.

In the second step, cyclization reactions of hippuric acide derivatives with corresponding benzaldehydes afforded the target compounds (E1-E10), which are analogs of 4-(substituted benzylidene)-2-(substituted phenyl) oxazol-5(4H)-on, were synthesized (see Scheme 2). Among the synthesized compounds, 9 out of 10 were original except, E1. Compound E1 was synthesized with one step reaction using hyppuric acid as starting material. ${ }^{6-17}$

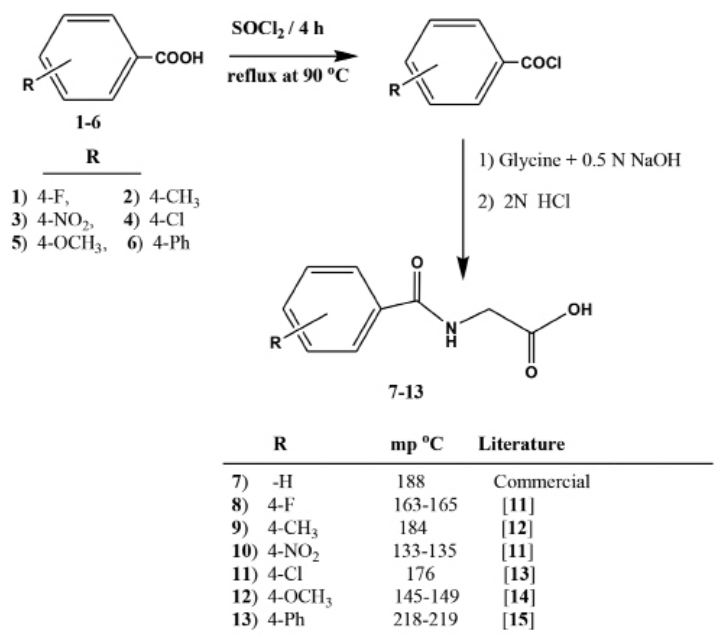

Scheme 1. Synthesis of hippuric acide derivatives (7-13)

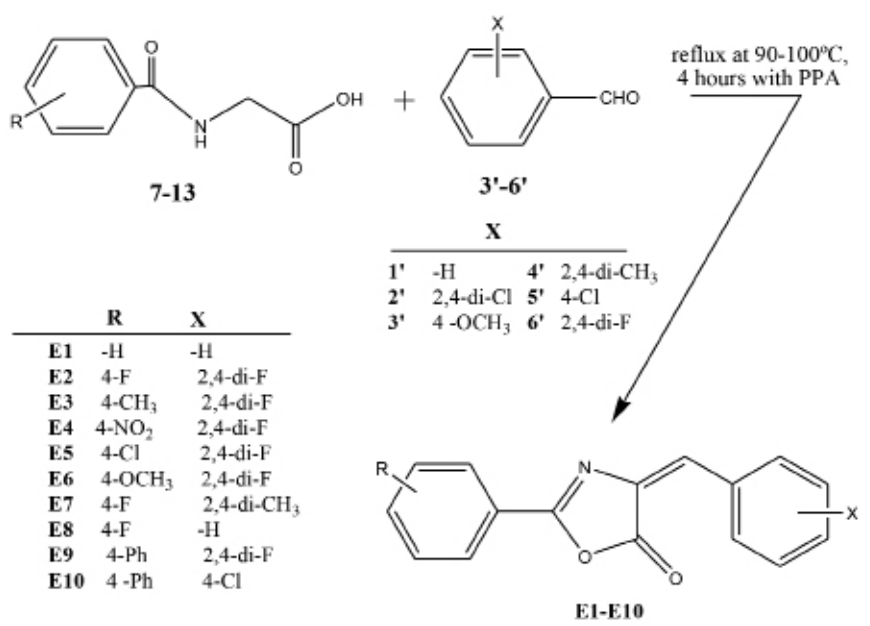

Scheme 2. Synthesis of the desired compounds (E1-E10).

\section{EXPERIMENTAL}

\section{Chemical methods}

Uncorrected melting points were measured on an Electrothermal 9100 capillary melting point apparatus. ${ }^{1} \mathrm{H}-\mathrm{NMR}$ and ${ }^{13} \mathrm{C}-\mathrm{NMR}$ spectra were recorded on a Varian Mercury $400 \mathrm{MHz}$ and 100 $\mathrm{MHz}$ FT spectrometer, chemical shifts ( $\delta$ ) are in ppm relative to tetramethylsilane, and coupling constants $(J)$ are reported in Hertz. Mass spectra were taken on a Waters Micromass ZQ using the Electrosprey Ionization (ESI) (+) method. Microanalyses were performed by Leco CHNS-932. All chemicals and solvents were purchased from commercial sources and used without furter purification. $p$-Fluorohippuric acid ${ }^{11}, p$-methylhippuric acid $^{12}, \quad p$-nitrohippuric acid ${ }^{11}, \quad p$-chlorohippuric acid ${ }^{13}$, $p$-methoxyhippuric acid ${ }^{14}$ and $p$-phenylhippuric acid ${ }^{15}$ were prepared according to the literature.

Synthesis of hippuric acid derivatives (7-13): One of appropriate benzoic acid derivatives 1-6 $(1.5 \mathrm{mmol})$ was refluxed in benzene (5 mL) with $\mathrm{SOCl}_{2}(5 \mathrm{~mL})$ for $2 \mathrm{~h}$ at $80^{\circ} \mathrm{C}$. Then solvent and excess of $\mathrm{SOCl}_{2}$ were evaporated completely. Glycine $(0.10 \mathrm{~mol})$ 
was dissolved in a $100 \mathrm{~mL}$ of $10 \%$ sodium hydroxide solution and appropriate benzoyl chloride $(0.12 \mathrm{~mol})$ was added portion-wise into it and the reaction mixture was shaked vigorously after each addition until all the chloride has been reacted for $1 \mathrm{~h}$ at $5^{\circ} \mathrm{C}$ and then at room temperature for $1 \mathrm{~h}$, again. $2 \mathrm{~N} \mathrm{HCl}$ added to the reaction mixture, until it was acidic to litmus paper. The resulting precipitate of sufficient benzoyl glycine so obtained was filtered, washed several times with cold distilled water, dried and crystallized form carbon tetrachloride (see Scheme 1).

General procedure for the preparation of 4-(substituted benzylidene)-2-(substituted phenyl) oxazol-5(4H)-on derivatives (E1-E10): Into a sample of polyphosphoric acid $(0.01 \mathrm{~mol})$, appropriate benzaldehyde $\left(1^{\prime}-6^{\prime}\right)$ and reasonable hippuric acid (7-13) $(0.01 \mathrm{~mol})$ were added. The mixture was heated in an oil bath $\left(90^{\circ} \mathrm{C}\right)$ for $4 \mathrm{~h}$ followed by pouring water into the reaction mixture. The precipitate formed from the mixture was then washed several times with water, air-dried and then purified by column chromatography with convenient solvent.

4-Benzylidene-2-phenyloxazole-5(4H)-on (E1): Light yellow crystal; (yield 75\%); ethyl acetate $/ n$-hexane $=1: 4 ; \mathrm{mp}: 169.4-$ $169.9^{\circ} \mathrm{C}\left(168-169^{\circ} \mathrm{C}{ }^{16,17}{ }^{1} \mathrm{H}-N M R\right.$ (Acetone- $\left.\mathrm{d}_{6}\right)$ : $\delta \mathrm{ppm}: 7.30\left(\mathrm{~s},{ }^{1} \mathrm{H}\right.$, $=\mathrm{CH}), 7.52-7.57\left(\mathrm{~m},{ }^{3} \mathrm{H}\right), 7.62-7.67\left(\mathrm{t},{ }^{2} \mathrm{H}\right), 7.71-7.75\left(\mathrm{t},{ }^{1} \mathrm{H}\right), 8.20(\mathrm{~d}$, $\left.{ }^{1} \mathrm{H}\right), 8.22\left(\mathrm{~s},{ }^{1} \mathrm{H}\right.$ ), 8.35-8.37 (d, ${ }^{2} \mathrm{H}$ ). ${ }^{13} \mathrm{C}$ NMR (Acetone- $\mathrm{d}_{6}$ ): $\delta \mathrm{ppm}$ : 171.7, 168.5, 138.6, 138.4, 138.3, 137.2, 135.96, 135.6, 134.0, 133.7, 132.9, 130.5; ESI-mass spectrometer (MS) m/z: $250.27(\mathrm{M}+1)$; Anal. Calculated for $\mathrm{C}_{16} \mathrm{H}_{11} \mathrm{NO}_{2}(\mathrm{C}, \mathrm{H}, \mathrm{N})$ : C 77.11, $\mathrm{H}$ 4.42, N 5.62; Found: C 76.77, H 4.26, N 5.97.

4-(2,4-Difluorobenzylidene)-2-(4-fluorophenyl)oxazole-5(4H)-on (E2): Light yellow solid; (yield 13\%), ethyl acetate/ $n$-hexane=

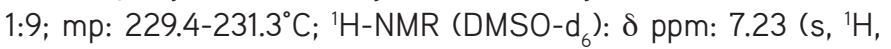
$=\mathrm{CH}), 7.31-7.36\left(\mathrm{t},{ }^{1} \mathrm{H}\right), 7.45-7.53\left(\mathrm{~m},{ }^{3} \mathrm{H}\right), 8.21-8.24\left(\mathrm{dd},{ }^{2} \mathrm{H}\right), 8.87-$ 8.9 (q, ${ }^{1} \mathrm{H}, \mathrm{H}_{5}$ ); ESI-MS m/z: $350.79(\mathrm{M}+47)$; Anal. Calculated for $\mathrm{C}_{16} \mathrm{H}_{8} \mathrm{~F}_{3} \mathrm{NO}_{2}(\mathrm{C}, \mathrm{H}, \mathrm{N}): \mathrm{C}$ 63.37, $\mathrm{H}$ 2.64, N 4.62; Found: $\mathrm{C} 63.02, \mathrm{H}$ 2.62, N 4.70, \%.

4-(2,4-Difluorobenzylidene)-2-p-tolyloxazole-5(4H)-on

(E3): Light yellow solid; (yield 29.3\%), ethyl acetate $/ n$-hexane $=1: 4$; mp: $196.9^{\circ} \mathrm{C} .{ }^{1} \mathrm{H}-\mathrm{NMR}$ (DMSO-d 6 ): $\delta \mathrm{ppm}: 2.44\left(\mathrm{~s},{ }^{3} \mathrm{H},-\mathrm{CH}_{3}\right.$ ), 7.19 (s, $\left.{ }^{1} \mathrm{H},=\mathrm{CH}\right), 7.32-7.36\left(\mathrm{t},{ }^{1} \mathrm{H}\right), 7.44-7.49\left(\mathrm{~m},{ }^{3} \mathrm{H}\right), 8.04-8.06\left(\mathrm{~d},{ }^{2} \mathrm{H}\right.$, $\mathrm{J}=8 \mathrm{~Hz}), 8.87-8.93\left(\mathrm{q},{ }^{1} \mathrm{H}\right)$; ESI-MS m/z: $346.81(\mathrm{M}+47)$; Anal. Calculated for $\mathrm{C}_{17} \mathrm{H}_{11} \mathrm{~F}_{2} \mathrm{NO}_{2}(\mathrm{C}, \mathrm{H}, \mathrm{N}): \mathrm{C}$ 68.23, $\mathrm{H}$ 3.68, N 4.44; Found: C 68.03, H 3.54, N 4.78, \%.

4-(2,4-Difluorobenzylidene)-2-(4-nitrophenyl)oxazole-5(4H)-on (E4): Light yellow solid; (yield 13.7\%); ethyl acetate/ $n$-hexane= 1:4; mp: $227.5^{\circ} \mathrm{C}$; ${ }^{1} \mathrm{H}-\mathrm{NMR}$ (DMSO-d $)$ : $\delta$ ppm: $7.34\left(\mathrm{~s},{ }^{1} \mathrm{H},=\mathrm{CH}\right.$ ), 7.37 (dd, ${ }^{1} \mathrm{H}, \mathrm{H}_{6}, \mathrm{~J}=2 \mathrm{~Hz}$ ), $7.51\left(\mathrm{t},{ }^{1} \mathrm{H}, \mathrm{H}_{3}, \mathrm{~J}=2 \mathrm{~Hz}, \mathrm{~J}=8 \mathrm{~Hz}\right.$ ), 8.368.48 ( $m,{ }^{4} \mathrm{H}, \mathrm{Ar}-\mathrm{H}$ ), 8.86-8.94 (q, ${ }^{1} \mathrm{H}, \mathrm{H}_{5}$ ). ESI-MS m/z: 377.96 $(\mathrm{M}+47)$; Anal. Calculated for $\mathrm{C}_{16} \mathrm{H}_{8} \mathrm{~F}_{2} \mathrm{~N}_{2} \mathrm{O}_{4} \cdot 0.1 \mathrm{H}_{2} \mathrm{O}: \mathrm{C} 57.88, \mathrm{H}$ 2.49, N 8.48; Found: C 57.48, H 2.59, N 8.29, \%.

4-(2,4-Difluorobenzylidene)-2-(4-chlorophenyl)oxazole-5(4H)on (E5): Light yellow solid; (yield 17.7\%); ethylacetate $/ n$ hexane $=1: 4$; mp: $238-240^{\circ} \mathrm{C}$; ${ }^{1} \mathrm{H}-\mathrm{NMR}$ (DMSO-d $)$ : $\delta \mathrm{ppm}: 7.22$ (s, ${ }^{1} \mathrm{H},=\mathrm{CH}$ ), 7.29-7.34 (t, $\left.{ }^{1} \mathrm{H}\right), 7.43-7.48\left(\mathrm{t},{ }^{1} \mathrm{H}\right), 7.69-7.72\left(\mathrm{~d},{ }^{2} \mathrm{H}\right.$, $\mathrm{J}=8 \mathrm{~Hz}$ ), 8.11-8.14 (d, $\left.{ }^{2} \mathrm{H}, \mathrm{J}=8 \mathrm{~Hz}\right), 8.84-8.90\left(\mathrm{q},{ }^{1} \mathrm{H}, \mathrm{H}_{5}\right)$; ESI-MS $\mathrm{m} / \mathrm{z}: 366.79(\mathrm{M}+47)$; Anal. Calculated for $\mathrm{C}_{16} \mathrm{H}_{8} \mathrm{ClF}_{2} \mathrm{NO}_{2}: \mathrm{C} 60.11$, H 2.52, N 4.39; Found: C 60.08, H 2.54, N 4.51, \%.
4-(2,4-Difluorobenzylidene)-2-(4-methoxyphenyl)oxazole5(4H)-on (E6): Light yellow solid; (yield 22\%), ethyl acetate/ $n$ hexane $=1: 4 ; \mathrm{mp}: 197.7^{\circ} \mathrm{C} ;{ }^{1} \mathrm{H}-\mathrm{NMR}\left(\mathrm{DMSO}-\mathrm{d}_{6}\right.$ ): $\delta \mathrm{ppm}: 3.90\left(\mathrm{~s},{ }^{3} \mathrm{H}\right.$, $\left.-\mathrm{OCH}_{3}\right), 7.14\left(\mathrm{~s},{ }^{1} \mathrm{H},=\mathrm{CH}\right), 7.18-7.21\left(\mathrm{~d},{ }^{2} \mathrm{H}, \mathrm{J}=8 \mathrm{~Hz}\right), 7.31-7.36(\mathrm{t}$, $\left.{ }^{1} \mathrm{H}\right), 7.43-7.49\left(\mathrm{t},{ }^{1} \mathrm{H}\right), 8.09-8.13$ (d, ${ }^{2} \mathrm{H}, \mathrm{J}=8 \mathrm{~Hz}$ ), 8.87-8.94 (q, ${ }^{1} \mathrm{H}$, $\mathrm{H}_{5}$ ); ESI-MS m/z: $316.8(\mathrm{M}+1)$; Anal. Calculated for $\mathrm{C}_{17} \mathrm{H}_{11} \mathrm{~F}_{2} \mathrm{NO}_{3}$ : C 64.76, H 3.49, N 4.44; Found: C 64.51, H 3.54, N 4.43, \%.

4-(2,4-Dimethylbenzylidene)-2-(4-fluorophenyl)oxazole-5(4H)on (E7): Light yellow solid; (yield $70.2 \%$ ), ethyl acetate $/ n$ hexane $=1: 9 ; \mathrm{mp}: 159.7-160.3^{\circ} \mathrm{C} ;{ }^{1} \mathrm{H}-\mathrm{NMR}\left(\mathrm{DMSO}-\mathrm{d}_{6}\right.$ ): $\delta \mathrm{ppm}: 2.34$ (s, $\left.{ }^{3} \mathrm{H},-\mathrm{CH}_{3}\right), 2.47\left(\mathrm{~s},{ }^{3} \mathrm{H},-\mathrm{CH}_{3}\right), 7.18\left(\mathrm{~s},{ }^{1} \mathrm{H}, \mathrm{H}_{3}\right), 7.21\left(\mathrm{~d},{ }^{1} \mathrm{H}, \mathrm{H}_{5}\right.$, $\mathrm{J}=8.4 \mathrm{~Hz}$ ), $7.39\left(\mathrm{~s},{ }^{1} \mathrm{H},=\mathrm{CH}\right), 7.48\left(\mathrm{t},{ }^{2} \mathrm{H}, \mathrm{Ar}-\mathrm{H}\right), 8.16-8.19\left(\mathrm{dd},{ }^{2} \mathrm{H}\right.$, Ar-H), 8.65 (d, ' $\left.{ }^{1} \mathrm{H}, \mathrm{H}_{6}, \mathrm{~J}=8.4 \mathrm{~Hz}\right)$; ESI-MS m/z: $328.7(\mathrm{M}+33)$; Anal. Calculated for $\mathrm{C}_{18} \mathrm{H}_{14} \mathrm{FNO}_{2}$ : C 73.22, H 4.75, N 4.75; Found: C 73.18, H 4.58, N 4.84, \%.

4-Benzylidene-2-(4-fluorophenyl)oxazole-5(4H)-on (E8): Yellow solid; (yield $19.5 \%$ ), ethyl acetate $/ n$-hexane $=1: 4 ; \mathrm{mp}: 218.2^{\circ} \mathrm{C}$; ${ }^{1} \mathrm{H}-\mathrm{NMR}$ (DMSO-d $\mathrm{d}_{6}$ : $\delta \mathrm{ppm}: 7.33\left(\mathrm{~s},{ }^{1} \mathrm{H},=\mathrm{CH}\right), 7.44-7.53\left(\mathrm{~m},{ }^{5} \mathrm{H}\right.$ ), 8.17-8.20 (dd, ${ }^{2} \mathrm{H}$ ), 8.27-8.30 (dd, ${ }^{2} \mathrm{H}, \mathrm{J}=2.4 \mathrm{~Hz}, \mathrm{~J}=8.4 \mathrm{~Hz}$ ); ESIMS m/z: $300.9(\mathrm{M}+33)$; Anal. Calculated for $\mathrm{C}_{16} \mathrm{H}_{10} \mathrm{FNO}_{2} \cdot 0.1 \mathrm{H}_{2} \mathrm{O}$ : C 71.42, H 3.82, N 5.21; Found: C 71.05, H 3.80, N 5.21, \%.

4-(2,4-Difluorobenzylidene)-2-[(4-phenyl)phenyl]oxazole-5(4H)on (E9): Light yellow solid; (yield $14.6 \%$ ), ethyl acetate $/ n$ hexane $=1: 4 ; \mathrm{mp}: 213.4-215.9^{\circ} \mathrm{C} ;{ }^{1} \mathrm{H}-\mathrm{NMR}\left(\mathrm{DMSO}-\mathrm{d}_{6}\right): \delta \mathrm{ppm}$ : $7.19\left(\mathrm{~s},{ }^{1} \mathrm{H},=\mathrm{CH}\right), 7.31-7.36\left(\mathrm{t},{ }^{1} \mathrm{H}\right), 7.42-7.53\left(\mathrm{~m},{ }^{4} \mathrm{H}\right), 7.76-7.87$ (d, $\left.{ }^{2} \mathrm{H}\right), 7.92-7.94\left(\mathrm{~d},{ }^{2} \mathrm{H}, \mathrm{J}=8.4 \mathrm{~Hz}\right), 8.17-8.19\left(\mathrm{~d},{ }^{2} \mathrm{H}, \mathrm{J}=8.4 \mathrm{~Hz}\right.$ ), 8.87-8.93 (q, 'H); ESI-MS m/z: $362.9(\mathrm{M}+1)$; Anal. Calculated for $\mathrm{C}_{22} \mathrm{H}_{13} \mathrm{~F}_{2} \mathrm{NO}_{2}$ : C 73.13, $\mathrm{H}$ 3.60, N 3.88; Found: C 73.16, H 3.95, N 3.83, \%.

4-(4-Chlorobenzylidene)-2-[(4-phenyl)phenyl]oxazole-5(4H)-on (E10): Yellow solid; (yield 13.9\%), ethyl acetat $/ n$-hexane $=1: 4$; mp: 193.2-195.9 ${ }^{\circ} \mathrm{C} ;{ }^{1} \mathrm{H}-\mathrm{NMR}$ (DMSO-d $\mathrm{d}_{6}$ : $\delta \mathrm{ppm}: 7.39$ (s, ${ }^{1} \mathrm{H},=\mathrm{CH}$ ), $7.47\left(\mathrm{t},{ }^{1} \mathrm{H}\right), 7.53-7.57\left(\mathrm{t},{ }^{2} \mathrm{H}\right), 7.63\left(\mathrm{~d},{ }^{2} \mathrm{H}, \mathrm{J}=8.4 \mathrm{~Hz}\right), 7.81\left(\mathrm{~d},{ }^{2} \mathrm{H}\right.$, $\mathrm{J}=7.2 \mathrm{~Hz}), 7.97\left(\mathrm{~d},{ }^{2} \mathrm{H}, \mathrm{J}=8.4 \mathrm{~Hz}\right), 8.22\left(\mathrm{~d},{ }^{2} \mathrm{H}, \mathrm{J}=8.4 \mathrm{~Hz}\right), 8.36$ (d, $\left.{ }^{2} \mathrm{H}, \mathrm{J}=8 \mathrm{~Hz}\right) ;{ }^{13} \mathrm{C}$ NMR $\left(\mathrm{CDCl}_{3}\right): \delta$ ppm: $124.31,127.48,127.85$, $128.73,129.20,129.29,129.49,130.04,132.30,133.74,133.95$, 137.47 139.86, 146.52, 163.97, 167.66; ESI-MS m/z=360.7 (M+1); Anal. Calculated for $\mathrm{C}_{22} \mathrm{H}_{14} \mathrm{CINO}_{2} \cdot 0.2 \mathrm{H}_{2} \mathrm{O}: \mathrm{C} 72.71, \mathrm{H} 3.99, \mathrm{~N}$ 3.85; Found: C 72.71, H 4.18, N 3.90, \%.

\section{Biological methods}

\section{Assay of lipid peroxidation}

Male albino Wistar rats (200-225 g) were used in the experiments. The animals were fed with standard laboratory rat chow and tap water add libitum. The animals were fasted for $24 \mathrm{~h}$ prior to sacrifice by decapitation under anesthesia. The livers were removed immediately and washed in ice-cold water and the microsomes were prepared, as described previously. ${ }^{18}$

NADPH-dependent lipid peroxidation (LP) was determined using the optimum conditions determined and described previously. ${ }^{18}$ $\mathrm{NADPH}$-dependent LP was measured spectrophotometrically by estimated the thiobarbituric acid reactant substances (TBARS). The amounts of TBARS were expressed in terms of $\mathrm{nmol}$ malondialdehyde/mg protein. The assay was essentially derived from the methods reported by Wills ${ }^{19,20}$ and modified by Bishayee and Balasubramanian. ${ }^{21} \mathrm{~A}$ typical optimized assay 
mixture contained $0.2 \mathrm{nM} \mathrm{Fe++}, 90 \mathrm{mM} \mathrm{KCl}, 62.5 \mathrm{mM}$ potassiumphosphate buffer $(\mathrm{pH}$ 7.4), a NADPH generating system consisting of $0.25 \mathrm{mM} \mathrm{NADP}+, 2.5 \mathrm{mM} \mathrm{MgCl}, 2.5 \mathrm{mM}$ glucose6-phosphate, $1.0 \mathrm{U}$ glucose-6-phosphate dehydrogenase and $14.2 \mathrm{mM}$ potassium phosphate buffer $(\mathrm{pH} 7.8$ ) and $0.2 \mathrm{mg}$ of the microsomal protein in a final volume of $1.0 \mathrm{~mL}$.

\section{Assay of ethoxyresorufin O-deethylase}

Ethoxyresorufin $O$-deethylase (EROD) activity was measured by the spectrofluorometric method of Burke et al. ${ }^{22}$. A typical optimized assay mixture contained $1.0 \mathrm{mM}$ ethoxyresorufin, $100 \mathrm{mM}$ Tris- $\mathrm{HCl}$ buffer ( $\mathrm{pH} 7.8$ ), NADPH generating system consisting of $0.25 \mathrm{mM} \mathrm{NADP}+, 2.5 \mathrm{mM} \mathrm{MgCl}, 2.5 \mathrm{mM}$ glucose6-phosphate, $1.0 \mathrm{U}$ glucose-6-phosphate dehydrogenase, and $14.2 \mathrm{mM}$ potassium phosphate buffer $(\mathrm{pH} 7.8)$ and $0.2 \mathrm{mg}$ liver microsomal protein in a final volume of $1.0 \mathrm{~mL}$.

\section{RESULTS}

Carpy et al. ${ }^{23}$ released that benzylic proton $(\mathrm{Ar}-\mathrm{CH}=\mathrm{C})$ of 4-(2-chloro-4,5-dimethoxybenzylidene)-2-methyl-5-oxazolone was at $6.91 \mathrm{ppm}$ and that if there were only one signal for the benzylic proton, this showed that $Z$-isomer existed. $E$-isomer is clarified by benzylic proton shift and absorbed magnetic resonance at up-field ( $7.5 \mathrm{ppm})$. Similar results have also been published by other researchers. ${ }^{24}$ Our final compounds showed parallel results at ${ }^{1} \mathrm{H}-\mathrm{NMR}$ spectra as singlet $\mathrm{Ar}-\mathrm{CH}=\mathrm{C}$ protone at 7.14-7.40 ppm.

4-Benzylidene-2-phenyloxazole-5(4H)-on (E1) has 16 carbon atoms. 4-(4-chlorobenzylidene)-2-[(4-phenyl)phenyl]oxazole$5(4 H)$-on (E10) has 18 carbon atoms and there are only 12 and 16 signals at ${ }^{13} \mathrm{C}$-NMR spectra, respectively. These findings are very normal and similar results were published by Younesi et al. ${ }^{25}$.

To examine the mass analysis of the final compounds (E1-E10), ESI-MS was used. Some of the desired compounds showed interesting results; E7 and E8 peaks were observed at $(M+33)$ and E2, E3, E4, and E5 peaks were observed at $(\mathrm{M}+47)$ at their mass spectra. These peaks were shown in the spectra of the molecules, because of keeping the solvents as methanol and ethanol. In 2003, Kawai et al. ${ }^{26}$ explained these formations based on quantum chemical calculations. These findings are similar to other researchers' results. ${ }^{27,28}$

Compound E10 has only one chlorine atom, because of that, as usual, $\mathrm{M}+$ and $\mathrm{M}+2$ (3:1) signals were observed in its mass spectrum.

For the EROD activity of the final compounds, $\mathrm{X}$ substitutents on the benzylidene moiety is more important than $\mathrm{R}$ substitutent, displayed in Scheme 2. As shown in Table 1, the most active compound on the microsomal EROD activity, E3 has 2,4-di-F as $\mathrm{X}$ substitutents on the benzylidene moiety. This compound interestingly enhanced the LP levels and not consistent with EROD results. Biphenyl substitution led to a reduction in the EROD activity newertheless there is no observation like this in the LP levels. It can be said that there is no problem with biphenyl substitution for LP levels because these two compounds have somewhat moderate activity against LP.
Table 1. EROD and LP activity results of the final compounds E1-E10

\begin{tabular}{llclc} 
Code & $\begin{array}{l}\text { EROD } \\
(\mathrm{pmol} / \mathrm{mg} / \mathrm{min})\end{array}$ & $\begin{array}{l}\% \text { of } \\
\text { control }\end{array}$ & $\begin{array}{l}\text { LP } \\
(\mathrm{nmol} / \mathrm{mg} / \mathrm{min})\end{array}$ & $\begin{array}{l}\% \text { of } \\
\text { control }\end{array}$ \\
\hline E1 & $8.71 \pm 0.51$ & 21 & $18.79 \pm 0.62$ & 115 \\
\hline E2 & $13.23 \pm 2.57$ & 32 & $15.89 \pm 2.06$ & 98 \\
\hline E3 & $4.47 \pm 0.04$ & 11 & $27.97 \pm 2.81$ & 172 \\
\hline E4 & $11.13 \pm 1.27$ & 28 & $26.59 \pm 3.21$ & 163 \\
\hline E5 & $10.38 \pm 0.64$ & 25 & $11.94 \pm 0.31$ & 73 \\
\hline E6 & $12.72 \pm 0.76$ & 30 & $9.01 \pm 0.86$ & 55 \\
\hline E7 & $*$ & $*$ & $*$ & $*$ \\
\hline E8 & $9.79 \pm 0.57$ & 24 & $6.91 \pm 0.86$ & 43 \\
\hline E9 & $20.92 \pm 0.28$ & 50 & $7.30 \pm 0.32$ & 45 \\
\hline E10 & $28.85 \pm 1.36$ & 69 & $9.40 \pm 0.32$ & 58 \\
\hline BHT & - & - & $5.68 \pm 0.22$ & 35 \\
\hline Caffeine & $6.41 \pm 0.99$ & 15 & - & - \\
\hline DMSO & $41.53 \pm 0.99$ & 100 & $16.25 \pm 1.45$ & 100 \\
\hline ER0D: & & & &
\end{tabular}

EROD: Ethoxyresorufin O-deethylase, LP: Lipid peroxidation, *Not tested

It is highly difficult to compare the results from different assays. The biggest problem is the lack of a validated assay that can reliably measure the antioxidant capacity of foods and biological samples, due to distinct antioxidant effects of chemicals which have already been noted in different in vitro assay systems. ${ }^{29}$ Antioxidants scavenge and prevent the formation of free radicals so they are highly important for the treatment of these kind of diseases mentioned above. For this reason, there has been an increasing interest in finding novel antioxidant compounds in recent years.

The activity patterns of compounds on LP, and EROD activity were dissimilar because each method relates to the generation of a different radical, acting through a variety of mechanisms, and the measurement of a range of end points at a fixed time point or over a time period. It should also be realized that the analytical methods of measurement and the conditions can lead to variable results for the same compound. ${ }^{30}$

Compounds E2 (2\%), E5 (27\%), E6 (45\%), E8 (57\%), E9 (55\%) and E10 (42\%) displayed highly limited inhibitory effects on LP and the rest of the compounds enhanced LP levels. Similar results, where thiadiazole derivatives enhanced LP levels were obtained in another study of ours on liver LP levels, too. ${ }^{31}$

\section{CONCLUSION}

In conclusion, a series of 4-(substituted benzylidene)-2(substituted phenyl) oxazole-5(4H)-on derivatives (E1-E10) were synthesized and their antioxidant activity were evaluated. The inhibition of LP, and its effects on hepatic cytochrome P450 dependent EROD enzyme were determined in rats in vitro. The most active analogue on the microsomal EROD activity was E3, which inhibited the microsomal EROD activity (89\%) and was 
similarly better than that of the specific inhibitor caffeine (85\%) at $10^{-3} \mathrm{M}$ concentration.

Compound E3 displayed significant antioxidant activity so needs to study on its analogues.

\section{ACKNOWLEDGEMENTS}

This work was supported by Ankara University Research Fund (Grant No: BAP 2005-08-030-50). The Central Laboratory of the Faculty of Pharmacy, Ankara University, Turkey supported the acquisition of the NMR, and Mass spectra and elemental analyses in this work.

Conflict of Interest: No conflict of interest was declared by the authors.

\section{REFERENCES}

1. Zhu M, Gokhale VM, Szabo L, Munoz RM, Baek H, Bashyam S, Hurley LH, Von Hoff DD, Han H. Identification of a novel inhibitor of urokinase-type plasminogen activator. Mol Cancer Ther. 2007;6:1348-1356.

2. Kuzikov AV, Dugin NO, Stulov SV, Shcherbinin DS, Zharkova MS, Tkachev YV, Timofeev VP, Veselovsky AV, Shumyantseva VV, Misharin AY. Novel oxazolinyl derivatives of pregna-5,17(20)-diene as 17 $\alpha$-hydroxylase/17,20lyase (CYP17A1) inhibitors. Steroids. 2014;88:66-71.

3. Das B, Rajarao AV, Sonalı R, Yadav A, Ray A, Pandya M, Rattan A, Mehta A. Synthesis and biological activity of novel oxazolidinones, Bioorg Med Chem Letters. 2009;19:6424-6428.

4. Diacon AH, Groote-Bidlingmaier F, Donald PR. A new 6-nitro-2,3dihydroimidazo[2,1-b]oxazole for the management of tuberculosis resistant to at least isoniazid and rifampicin. Expert Opinion on Orphan Drugs. 2014;2:87-94.

5. Garg P, Chaudhary S, Milton MD. Synthesis of 2 aryl/heteroaryloxazolines from nitriles under metal and catalyst-free conditions and evaluation of their antioxidant activities. J Org Chem. 2014;79:8668-8677.

6. Temiz-Arpaci O, Coban T, Tekiner-Gulbas B, Can-Eke B, Yildiz I, AkiSener E, Yalcin I, Iscan MA. Study on the antioxidant activities of some new benzazole derivatives. Acta Biologica Hungarica. 2006;57:201-209.

7. Ames BN, Shigenaga MK, Hagen TM. Oxidants, antioxidants, and the degenerative disease of aging, Proc Natl Acad Sci USA. 1993;90:79157922.

8. Hagen TM, Yowe DL, Bartholomew JC, Wehr CM, Do KL, Park JY, Ames BN. Mitochondrial decay in hepatocytes from old rats: membrane potential declines, heterogeneity and oxidants increase. Proc Natl Acad Sci USA. 1997; $94: 3064-3069$

9. Hagen TM, Ingersoll RT, Wehr CM, Lykkesfeldt J, Vinarsky V, Bartholomew $J C$, Song MH, Ames BN. Acetyl-L-carnitine fed to old rats partially restores mitochondrial function and ambulatory activity. Proc Natl Acad Sci USA. 1998;95:9562-9566.

10. Beckman KB, Ames BN. The free radical theory of aging matures. Physiol Rev. 1998;78:547-581.

11. Benvenuti S, Severi F, Costanino L, Vampa G, Melegari M. Synthesis and aldose reductase inhibitory activity of benzoyl-amino acid derivatives. Farmaco. 1998;53:439-442.

12. Mistry RN, Desai KR. Studies on Synthesis of Some Novel Heterocyclic Azlactone Derivatives and Imidazolinone Derivatives and their Antimicrobial Activity. E-Journal of Chemistry. 2005;2:42-51.

13. Novello NJ, Miriam SR, Sherwin CP. Comparative Metabolism of Certain Aromatic Acids. IX. Fate of some halogen derivatives of benzoic acid in the animal body. J Biol Chem. 1926;67:555-566.
14. Mariappan G, Saha BP, Datta S, Kumar D. Haldar PK. Design, synthesis and antidiabetic evaluation of oxazolone derivatives. J Chem Sci. 2011;123:335-334.

15. Tzschucke CC, Bannwarth W. Fluorous-silica-supported perfluoro-tagged palladium complexes catalyze Suzuki couplings in water. Helvetica Chimica Acta. 2004;87:2882-2889.

16. Oelschlaeger H, Seeling A, Radman M, Bockhard H. E/Z-ratio acid stability of halogenated benzylidene derivatives formed during the detection of glycine conjugates. Pharmazie. 2000;55:825-828.

17. Yu C, Zhou B, Su W, Xu Z. Erlenmeyer synthesis for azlactones catalyzed by Ytterbium (III) Triflate under solvent-free conditions. Synthetic Communications. 2006;36:3447-3453.

18. İșcan M, Arinç E, Vural N, Ișcan MY. In vivo effects of 3-methylcholantrene, phenobarbital, pyretrum and 2,4,5-T isooctylester on liver, lung and kidney microsomal mixed-fuction oxidase system of guinea-pig: a comparative study. Comp Biochem Physiol. 1984;77:177-190.

19. Wills ED. Mechanism of lipid peroxide formation in animal tissues. Biochem J. 1966;99:667-676.

20. Wills ED. Lipid peroxide formation in microsomes. Relationship of hydroxylation to lipid peroxide formation. Biochem J. 1969;113:333-341.

21. Bishayee $S$, Balasubramanian AS. Lipid peroxide formation in rat brain. $J$ Neurochem. 1971;18:909-920.

22. Burke MD, Thompson S, Elcombe CR, Halpert J, Haaparanta T, Mayer RT. Ethoxy-, Pentoxy-, and benzyloxyphenoxazones and homologues, a series of substrates to distinguish between different induced cytochromes P-450. Biochem Pharmacol. 1985;34:3337-3345.

23. Haasbroek PP, Oliver DW. Structure of 4-(2-chloro-4,5dimethoxybenzylidine)-2-methyl-5-oxazolone X-ray and NMR stud. J Chem Cryst. 1998;28:811-814.

24. Päsha MA, Jayäshankara VP, Venugopala KN, Rao GK. Zinc Oxide $(\mathrm{ZnO})$ : An efficient catalyts for the synthesis of 4-arylmethylidene-2phenyl 5(4H)-oxazolones having antimicrobial activity. J Pharm Toxicol. 2007;2:264-270.

25. Younesi A, Sorotskaya LN, Krapivin GD. Unexpected Spiroproducts from the Reaction of N-Benzoylglycine with ortho-Formylbenzoic Acids 3,5-dioxo-2-phenyl-1,3-dihydrospiro[indene-2,4-[1,3]oxazol]-1-yl Acetates: Establishments of Their Structure. J Chinese Chem Soc. 2009;56:619625.

26. Kawai A, Tanaka H, Nakashima Y, limori T, Tsuji K, Obi K, Shibuya K. Protonation and multi-hydrogenation of benzophenone (BP) in BP/ toluene and BP/ethanol binary cation clusters. Chemical Physics Letters. 2003;381:354-361.

27. Huang N, Siegel MM, Kruppa GH, Laukien FH, Automation of a Fourier Transform lon Cyclotron Resonance Mass Spectrometer for Acquisition, Analysis, and E-mailing of High-Resolution Exact-Mass Electrospray Ionization Mass Spectral Data. J Am Soc Mass Spectrom. 1999;10:11661173.

28. Kobetic R, Gembarovski D, Baranovic G, Gabelica V. ESI-MS studies of mixed-ligand $\mathrm{Fe}$ (II) complexes containing 1,10-phenanthroline and 1,10-phenanthroline-5,6-dione as Ligands. J Mass Spectrom. 2008;43:753764.

29. Ates-Alagoz Z. Antioxidant activities of retinoidal benzimidazole or indole derivatives in vitro model systems. Curr Med Chem. 2013;20:4633-4639.

30. Kuş C, Ayhan-Kilcigil G, Ozbey S, Kaynak FB, Kaya M, Coban T, Can-Eke B. Synthesis and antioxidant properties of novel $\mathrm{N}$-methyl-1,3,4-thiadiazol2-amine and 4-methyl-2H-1,2,4-triazole-3(4H)-thione derivatives of benzimidazole class. Bioorg Med Chem. 2008;16:4294-4303.

31. Kus C, Ayhan-Kilcigil G, Can-Eke B, Iscan M. Synthesis and antioxidant properties of some novel benzimidazole derivatives on lipid peroxidation in the rat liver. Arch Pharm Res. 2004;27:156-163. 